\title{
New System for Korean Nursing Home Contracted Physicians Began in 2017
}

\author{
Hyuk Ga \\ Institute of Geriatric Medicine, Incheon Eun-Hye Hospital, Incheon, Korea \\ Corresponding Author: Hyuk Ga, MD, PhD \\ Institute of Geriatric Medicine, Incheon Eun-Hye Hospital, 21, 132Beon-Gil, Simgok-ro, Seo-gu, Incheon 22711, Korea \\ Tel: +82-32-590-8701, Fax: +82-32-566-4335, E-mail: gahyuk@gmail.com
}

Received: February 14, 2017, Revised: February 22, 2017, Accepted: March 1, 2017

Since the national long-term care insurance program was implemented in Korea in 2008, there has been an abrupt increase in the number of nursing homes and residents, from 128 nursing homes and 7,864 residents in 2001 to 5,063 nursing homes and 160,115 residents in $2015^{1,2)}$. Senior citizens who are 65 years of age or older or younger individuals who have chronic senile diseases are eligible for long-term care insurance services. long-term care insurance recipients are classified into 5 categories and must fall within at least the upper 3 categories to be admitted to nursing homes ${ }^{3)}$. Therefore, the quality of care delivered to them is important, and the caregiving workforce is among the most powerful variables $^{4}$. According to the Elderly Welfare Law, one physician and one registered or assistant nurse are needed for nursing homes with capacities of 10 beds or more ${ }^{5}$. However, in recent studies, only $68 \%-80 \%$ of nursing homes were reported to have regularly visiting, contracted physicians, and $72 \%$ of the physicians were not paid at all ${ }^{6,7)}$. Realizing the lack of quality medical care for residents, the Ministry of Health and Welfare obtained experts' opinions in 2014 and revised the regulation for contracted physicians in 2016,89). According to the new regulations that were implemented on January 1, 2017, visiting fees are directly given to the physicians from the National Health Insurance Corporation through their affiliated hospitals, local committees recommend qualified physicians to those nursing homes that are recruiting new physicians, the completion of a 3-hour certifying education program is necessary, each resident should be met by a physician at least twice per month, and each physician can ask for a managing payment for 50 residents at most per visit (Table 1). Managing fees are 14,410 Korean won (KRW) for the first visit and 10,300 KRW thereafter, and there is an additional visiting fee of 53,000 KRW per nursing home visit. By February 2017, 29 educational programs to certify nursing home physicians had been held nation-wide by the Korean Medical Association, with 5,601 physicians having participated.

There are still some problems to be discussed further. First, some caregivers refuse to pay the residents' share

Table 1. Comparison of past and current regulations related to nursing home contracted physicians

\begin{tabular}{lll}
\hline \hline Changed Features & \multicolumn{1}{c}{ Past (before 2017) } & New (since 2017) \\
\hline $\begin{array}{l}\text { Eligibility } \\
\text { Appointment }\end{array}$ & $\begin{array}{l}\text { Physicians, Korean traditional physicians } \\
\text { Random, or optional by nursing home } \\
\text { directors } \\
\text { Registration items }\end{array}$ & $\begin{array}{l}\text { Phecommended by local physicians' societies } \\
\text { Name, Phone numbers }\end{array}$ \\
$\begin{array}{l}\text { Education } \\
\text { Visiting frequency } \\
\text { Maximum residents managed per day } \\
\text { Payment }\end{array}$ & $\begin{array}{l}\text { Not required } \\
\text { One visit per 2 weeks }\end{array}$ & $\begin{array}{c}\text { Physicians' specialties, completion of educational } \\
\text { programs added }\end{array}$ \\
& None or variable & $\begin{array}{l}\text { Three hour on-site education* must be completed } \\
\text { Two visits per month }\end{array}$ \\
& & $\begin{array}{l}\text { Fifty residents per day } \\
\text { Fixed and delivered to physicians directly from } \\
\text { National Health Insurance Corporation }\end{array}$
\end{tabular}

\footnotetext{
This certifying education program is composed of 4 parts: (1) common clinical problems in nursing facilities, (2) the long-term care insurance and contracted physician system, (3) the roles of contracted physicians in nursing facilities, and (4) common procedures in nursing facilities.
} 
of costs for the physicians, but there is no legal force through which to obtain it. Second, some hospitals or physicians are trying to monopolize the management of neighboring nursing homes, so several local physicians' societies have set a limit on the number of residents each hospital may manage. Third, as the roles and qualities of contracted physicians are becoming central issues in the Korean long-term care system, the border between nursing homes and geriatric long-term care hospitals has become indistinct, and physicians are expressing concerns ${ }^{10)}$.

Conflicts of Interest Disclosures: The researcher claims no conflicts of interest.

\section{REFERENCES}

1. Park IS, Kim SK. Korean elderly long-term care insurance system and long-term care hospital. J Korean Geriatr Soc 2008;12:68-73.

2. Statistics Korea: Tables of statistics [Internet]. Daejeon: Statistics Korea; [cited 2017 Feb 13]. Available from: http://kosis.kr/ wnsearch/totalSearch.jsp.

3. Kim S, Won CW, Ga H. Nursing homes and their contracted doctors: Korean experience. J Am Med Dir Assoc 2015;16:533-4.

4. Katz PR, Quail P, McBryde MJ, Karuza J. Physician practice in the nursing home: exploring new models. CGS J CME 2011; 1:23-7.

5. Elderly Welfare Law [Internet]. Sejong: Korea Ministry of Government Legislation; c1997-2017 [cited 2017 Feb 13]. Available from: http://www.law.go.kr/lsInfoP.do?lsiSeq=178129\&efYd= 20161230\#0000.

6. Kwon SM, Kim HS, Won CW, Lee JY, Kim H, Jung YI, et al. Improvement plan for geriatric medical (care) service system. Seoul: National Health Insurance Corporation; 2013.

7. Park JH, Won $\mathrm{CH}$, Cho KH, Roh YK, Sunwoo D, Lee KK, et al. Improvement plan for nursing home contracted physicians. Sejong: Ministry of Health and Welfare; 2011.

8. Won CW, Roh YK, Ga H, Kim SY. Reinforcement of nursing home contracted physicians' guidance and development of teaching material. Sejong: Ministry of Health and Welfare; 2014.

9. Korean Medical Association. Standard teaching material for nursing home physicians. Seoul: Korean Medical Association; 2016.

10. Telemedicine in nursing homes? Stop expansion of visiting physicians' roles in nursing homes [Internet]. Seoul: Medical Times; c2003-2015 [cited 2017 Feb 13]. Available from: http://www.medicaltimes.com/News/1106488. 